Rigina TURUNen (Helsinki)

\title{
Double encoding of nominal and adjectival predicates: A study of the nominative-translative switch in Erzya
}

\begin{abstract}
In Erzya the nominal and adjectival predicates of 'be' copula constructions display double encoding, which takes the form of a nominative-oblique case opposition. The universal tendency is for this opposition to be conditioned by time-stability: encoding in the nominative is used in referring to situations which are relatively stable in time since the oblique encoding - in Erzya the translative - emphasizes the temporary nature of the situation. In some constructions, however, the Erzya translative seems to be in free variation with the nominative. Also clauses referring to stable states, such as identificational statements, may display the translative. Consequently, time-stability is not the only factor constraining the employment of the Erzya translative.
\end{abstract}

\section{Introduction}

The present study focuses on case variation between the nominative and translative in Erzya. The Erzya translative is a label for non-spatial cases carrying the meaning of a temporary state of being or function, often equivalent to English 'as N' ('as a child', 'as a doctor'). Many Erzya verbs have a valency pattern including a translative. In this paper, the focus is, however, not on these verbs, but on the construction "being an $\mathrm{N}$ ", in which $\mathrm{N}$ is either in the nominative or translative. Importantly, the construction types that receive attention in the present study bear only vaguely or not at all the semantic content "being as an N". This construction type is referred to as nominal predication, proper inclusion (see discussion in Turunen 2009) or like Creissels (2011), identificational predication. The use of a marked case form or adposition with the noun phrase in predicate function is relatively uncommon in the languages of the world (Creissels ibid.), Erzya being one of the languages that makes an exception to the general tendency.

In the present paper those language-specific cases that are descriptive categories are exceptionally written with lower case, and not capitalized letters, see Haspelmath (2010). Thus, for example, the Erzya translative, Finnic essive and Russian instrumental are language-specific terms. These cases encode partly similar semantic contents and fall under the definition of functive (Creissels ibid.). Functive serves as a crosslinguistic comparative concept: in specific languages the case may have other labels such as the ones described above. Creissels uses the label functive for a comparative concept defined as 'a possible role for noun phrases in predicative constructions headed by verbs encoding events in which participants are involved'. Further characteristics of functive encoded nouns, including the Erzya translative are, in Creissels' words, that a noun phrase $\mathrm{N}$ in functive role does not represent an entity involved in the event, but it attributes the property of being an $\mathrm{N}$ to a participant represented by 
another noun phrase included in the construction. Thus, it is actually the whole construction " $\mathrm{N}$ was/will be N/A-TRA that must be studied, specifying the relationship between the copula and other elements.

In the present study the functions of the Erzya translative are investigated especially in clauses that contain a semantically empty copula. Consequently, in Erzya a translative encoded noun may function as the main semantic predicate of the clause, and as such it is not dependent on the verb 'be' in static expressions. The general aim of this study is to reveal those factors that affect the occurrence of the translative in $u l^{\prime}(n)$ ems 'be' copula constructions. The reasons behind the choice of the translative instead of the nominative appear to be complicated, and therefore, the present paper serves only as a starting point for a wider study that will hopefully be done in the future. The study takes also the first steps in the investigation of possible contactinduced change in Erzya. To shed light on the possible influence of Russian, I shall compare the occurrence of the translative in Standard Erzya, folklore, spoken data and translations from Russian, see Section 2.

The structure of this study is as follows. After introducing the data in Sections 2 and 3, the key examples of Erzya constructions are given in Section 4. In Section 5, the theory of time-stability is discussed, and the patterns of the Finnic languages as well as Russian are briefly discussed in light of the time-stability factor. In Section 6 the basic semantic contents of the translative in copula constructions are defined. Section 7 pays particular attention to those constructions in which the Erzya translative seems to be in free variation with the nominative, and the term semantically vague translative is introduced. Especially discussed are those factors effecting the nominative-translative switch, such as tense and time-stability, lexical class and negation. In Section 8 the occurrence of the translative in different genres in Erzya is briefly examined in light of data collected by the author. Section 8 compares original Russian sentences to sentences translated by Erzya students, aiming to illustrate the extent to which patterns are (dis)similar in Erzya and Russian. My working hypothesis is that if the expansion of the translative is (at least partly) explainable on the basis of Russian influence, it would be more likely to occur in translations from Russian than in other genres. However, in order to answer questions concerning the role of language-internal and contact-induced mechanisms in the development of the NP + ul'́ems + NP + TRA construction, further investigation will certainly be necessary. As a conclusion, there is a brief summary of the findings of the study.

\section{Data}

In order to obtain the most far-reaching and reliable results possible, many types of data were employed in this study, which actually forms part of a larger project. The data collected from all three types of written sources in Erzya contains about 5000 nonverbal nominal, adjectival and locational predicate constructions. Among these constructions, translative encoding occurs in only 145 clauses, and consequently the 
results of the present paper must be regarded as preliminary, since it is certain that a larger database will be necessary for any detailed study.

The written material has mainly been collected from the Volga server of the Research Unit for Volgaic Languages, University of Turku. The part of the corpus used for the purposes of the present study consists of unanalysed texts collected from the Erzya journal Siatko, namely issues 2, 3, 4, 7 and 10 from 2003. The sources are referred to by the number of the journal. Because the corpus is electronic, page numbers are not shown. The advantage of using Siatko is that the texts were written by many different authors and thus represent many idiolects. Furthermore, they represent different genres: there are short stories, poetry, and articles on literature and history as well. For the second type of written data, three novels by different authors and two books consisting of prose written by several authors were chosen. A list of these works is included at the end of this paper. This material is referred to using the name of the author and the novel's publication date.

Further folklore material has been taken from Mordwinische Volksdichtung I-III, collected by Heikki Paasonen at the close of the 19th century. The genre of this material is mainly folkloric poetry. This data is basically vernacular, but when referred to in the present study, it is labelled as folklore data in comparison to the real vernacular data, described in more detail below.

Conversations with 16 Erzya women were recorded in Mordovia during the summer of 2005 by Svetlana Motorkina for the purposes of this study. The author recorded three conversations in Hungary in which two Erzya and three Moksha informants participated. All the data on tape was then analysed by the author. During the conversations, the informants were asked to speak about themselves, their family and childhood, as well as the surroundings in which they lived. The total length of the conversations is about five hours. All informants were women between 17 and 57 years of age, and 11 of them had studied at the Department of Finno-Ugric and Comparative Linguistics of Saransk University. A detailed background of the informants is not provided, as the data displays homogeneous predication patterns regardless of possible sociolinguistic factors. ${ }^{1}$ If examples are taken from spoken data, the initials of the informant are mentioned after the spoken phrase.

Questionnaires were also employed especially in order to gather data. The questionnaire data unexpectedly offered additional information on the nominative-translative switch. In the autumn of 2006 Svetlana Motorkina, an Erzya speaker and teacher at the University of Saransk, kindly gathered data intended for this study. The research was carried out at the Department of Finno-Ugric and Comparative Linguistics of Saransk University. The first questionnaire was completed by 19 Erzya and seven Moksha students, then 23 questionnaires were completed by Erzya and 15 by Moksha students. Erzya and Moksha students translated Russian sentences with nonverbal predicates into their respective mother tongues. Both questionnaires, planned by the

1 The data does, however, offer interesting material for the study of other phenomena more influenced by sociolinguistic factors. 
author, consisted of 15 different kinds of nonverbal predicate clauses. The students were asked to fill in the questionnaires in their own dialect. One of the questionnaires was incomplete, suggesting that the informants' skills in Erzya were not good enough for translating the sentences. Presumably all the informants are bilingual in Erzya or Moksha and Russian. The aim of the study assisted by the questionnaires was to collect comparative data in order to obtain more information concerning the present-day language. Although the translation method of collecting data has many disadvantages, as reported in Turunen (2010), this method does reveal significant differences between Erzya and Moksha. Most importantly, the differences between the two Mordvin languages demonstrated that even when the data is based on translations, predication patterns similar to Russian were not attested in Moksha. The fact that they were attested frequently in Erzya can therefore not be explained simply by the fact that the informants produced translations from Russian.

In order to obtain as informative a picture as possible of the nominative-translative switch, native speakers with a good knowledge of Erzya grammar have cooperated with the author during this study. Important partners have been the two Erzya lecturers at the University of Szeged, now at the University of Saransk, Svetlana Motorkina and Nina Kazaeva. The clauses containing the translative were all checked by Kazaeva and Motorkina. The author asked several questions concerning the switch and the possible factors behind it. The reasons for choosing the translative instead of the nominative were often very hard to specify even for Kazaeva and Motorkina, ${ }^{2}$ which must be due not to their linguistic competence, but rather to the fact that the factors are complicated and manifold.

\section{Occurrence of the translative in the Siatko data}

The following table summarises those constructions in which translative encoding occurred in NP that function as a semantic predicate. In the written data collected from prose and from Siatko, in 145 past tense copula clauses the predicate nominal was inflected in the translative. In $278 \mathrm{ul}^{\prime}\left(n^{n}\right)$ ems copula constructions the predicate noun or adjective was in the nominative. In 581 past tense nominal and adjectival predicate clauses the predication pattern was the predicative suffix construction, in which translative encoding is not possible. The clauses often contained more than one translative encoded noun, and consequently the table contains a total of 150 clauses. By specific construction types are meant those constructions in which the translative occurs obligatorily. These constructions are presented in Section 6 and include both the translative of similarity and the translative of clear non-inherent relationship.

2 I am deeply grateful for Nina Kazaeva and Svetlana Motorkina for their patience and help. In addition I wish to thank Ágnes Felföldi for helping me in practical concerns. I would also like to express my gratitude to Riho Grünthal, Jussi Ylikoski and the two anonymous referees for their comments on this paper. 
Those constructions in which the noun denotes occupation, function or status may contain a noun or a present tense participle as their predicate. Those clauses in which predicates of these kinds occurred often - but not necessarily - contained a reference to a specific point in time. Also, other types of class-membership clauses with translative coded nouns occurred. In identificational clauses the translative was quite rare. The translative was chosen more often if the predicate was a noun than if it was an adjective. The adjectival pronouns lija, iśtamo and kodamo were, however, encoded relatively often in the translative.

Noun in specific constructions 23

Noun of occupation $\quad 52$

Present participle $\quad 17$

$\begin{array}{ll}\text { Other noun } & 37\end{array}$

Identificational clause $\quad 4$

Adjective 5

Adjectival pronoun (lija, iśtamo, kodamo) 10

Quantifier 2

Total 150

Table I.The occurrence of the translative in standard written data collected from Siatko.

In the material collected from the Erzya parts of Mordwinische Volksdichtung, the translative was rarely employed in nonverbal predicate clauses containing a copula inflected in the present or past tense, see Example (1).

(1) vaśńa ulńn-i-ń śece-nk śedej-orm'i-ńe-ks

earlier be-1PST-1SG heart.INE-2PL heart-ache-DIM-TRA

p'iŕa-so-nk p'iŕa-orm'i-ńe-ks

(MV II 477)

head-INE-2PL head-ache-DIM-TRA

'Earlier I was in your heart as a heartache, in your head as a headache.'

In Example (1) the translative encoding is motivated, and it encodes the similarity between the subject referent and translative encoded referent.

\section{Key examples of Erzya nominative-translative switch}

The encoding of nominal and adjectival predicate clauses in Erzya displays morphosyntactic variation. There are two predication patterns in the present tense. Either the nonverbal predicate is conjugated with the predicative suffix, as illustrated in Example (2), or the subject and predicate are juxtaposed without inflectional person markers, as illustrated in Example (3). In Example (2), the subject is in the second person singular, which is encoded with the free pronoun ton as well as synthetically with the nominal 
predicate komissarat. In Example (3), the subject ton and the predicate noun pisatel' are simply juxtaposed, and the predicate is not inflected in the second person singular.

Subject NP + Predicate Adjective/Noun + person

(2) Ton komissara-t, śeks teve-ś=kak té-toń.

$2 \mathrm{SG}$ commissar-2SG therefore thing-DEF=too this $-2 \mathrm{SG}$.GEN

'You are a commissar, therefore this is your business.'

(Siatko 2003: 4)

Subject NP + Predicate Adjective/Noun

(3) Aŕś-i-ńek, ton pisatél.'

(Siatko 2003: 2)

think-1PST-1PL 2SG author

'We thought you are an author.'

In these constructions, the predicate nouns and adjectives are in the nominative case. The predicate nouns of class-membership predication are indefinite, as definite nouns occur in identificational clauses (these two types are semantically and morphologically distinguished in Erzya, see Turunen 2009 and 2010a). In Standard Erzya, the main pattern is the predicative suffix construction. In the third person singular, juxtaposition is the only pattern. Simple juxtaposition may be employed in the case of 1 st and 2 nd person subjects as well, which is more typical of nominal than adjectival predication (for a detailed discussion see Turunen 2009).

The past tense nominal and adjectival predications are encoded in two patterns. Firstly, Erzya differentiates between the so-called 1st and 2nd past tense in verbal predication. Verbal predicates are inflected in the 2nd past tense to encode usual or continuous actions, which precede some other action (Cygankin et al. 2000: 163). The opposition between the 1st and 2nd past tense is neutralized in the case of nonverbal predicates: there is no semantic difference between the synthetic 2 nd past tense form and the analytic construction built with the $u l^{\prime}\left(n^{\prime}\right) e m s$ copula (see Turunen 2010a). In the synthetic pattern, the nonverbal predicate is inflected in tense and person with the past tense predicative suffix, as illustrated in the first clause of Example (4). In this clause, the nominal predicate lomanel' is in the nominative, and it is conjugated in the past tense of the nonverbal conjugation. (The second clause in Example (4), which is also a nominal predicate construction, will be of greater relevance to the discussion below.) The other possible predication pattern is to employ the ulnems copula illustrated in Example (5). The auxiliary is inflected in tense and person and the nominal predicate is in the nominative. The nominal predicate agrees in number with the subject, like jalgat in Example (5). 
Subject NP + Predicate Adjective/Noun + PST + PERSON

(4) Laŕionov śorma-s-gramota-s sod-ića lomań-el',

Larionov writing-ILL-reading-ILL know-PTCP.PRS human-2PST.3SG

ve ška-sto ulńe-śs pisare-ks.

(Siatko 2003: 7)

one time-ELA be-1PST.3SG clerk-TRA

'Larionov was a person that could read and write, who had once been a clerk.'

Subject NP $+u l^{\prime}(\dot{n})$ ems copula + Predicate Noun/Adjective in Nominative

(5) Siń ulńe-ś- $t^{\prime}$ a javoviks jalga-t.

3PL be-1PST-3PL NEG separable friend-PL

(Erkay 1991: 17)

'They were inseparable friends.'

There are two different types of copula constructions for encoding the predicate noun or adjective. In the first type, the nonverbal predicate is in the nominative as illustrated in Example (5). In the second type, the noun or adjective is declined in the translative, as is the noun pisareks in the second clause of Example (4). A similar construction is presented in Example (6), in which the noun jalgaks is in the translative.

Subject NP $+u l^{\prime}(\dot{n})$ ems copula + Predicate Noun/Adjective + Translative

(6) Vaśeńće-ś - Ludmila Viktorovna marto

first-DEF Lyudmila Viktorovna with

miń ulń-i-ńek student jalga-ks.

(Siatko 2003: 2)

1PL be-1PST-1PL student friend-TRA

'The first thing: Lyudmila Viktorovna and I were fellow students.'

Encoding in the translative could be replaced by nominative encoding in Examples (4) and (6); the denotation would be similar even if the predicate were in the nominative. If it were in the nominative, it would agree in number: jalga-t. Indefinite nouns inflect in the plural only in the nominative, and most case suffixes can be attached to definite plural stems. The Erzya translative suffix cannot, however, be added to definite plural stems. The lack of a singular-plural opposition in the translative makes it specific with reference to other Erzya case suffixes. (Bartens 1999: 99.)

The translative case also switches with the nominative case in nominal and adjectival predicate constructions in which the ulems copula is inflected in the present tense. These clauses refer to the future (Cygankin et al. 2000: 164; Koliadenkov 1954: 187). They report either a dynamic relation of becoming something, or a stative relation of being something in the future. Translative encoding is illustrated in Example (7).

Subject NP + ulems copula + Predicate Noun Translative

(7) Nej ton ul'at moń koźajka-ks.

(Siatko 2003: 7)

now $2 \mathrm{SG}$ be-2SG my wife-TRA

'Now you shall be my wife.' 
The present treatise concentrates on describing the translative-nominative switch in clauses such as (4), (5) and (6), and to a lesser extent, in those clauses denoting the future, as illustrated in Example (7). Stassen's (1997: 188-193; 2001) cross-linguistic data suggests that a lower degree of time-stability is connected to the employment of the oblique case, such as the Erzya translative. The working hypothesis is that the nominative case occurs in time-stable constructions (5), since the construction in (6) makes reference to a more temporary relationship. The relative time-stability factor must, nevertheless, be studied taking into account the whole construction, and not only the encoding of the predicate NP. In Erzya, the translative also has other semantically clearer functions in constructions with an $u l^{\prime}(n)$ ')ems copula. These will be discussed in Section 6.

It is noteworthy that the occurrence of the translative case depends on the predication pattern, since nominal and adjectival predicates may be encoded in either the nominative or translative case when predication is made using the $u l^{\prime}(\hat{n})$ ems copula (however see below for constructions without a copula). In the present treatise only $u l^{\prime}(n)$ ems copula constructions are investigated. The domain of Erzya nominal and adjectival predication displays considerable morphosyntactic variation described in other studies such as Turunen $(2009,2010 a, 2010 b, 2011)$.

\section{The nominative-oblique switch and time-stability}

Stassen $(2001 ; 1997: 188-193)$ demonstrates that there are languages that display double encoding of nonverbal predicates, which takes the form of a nominative-oblique case opposition. In most languages this double encoding mirrors a semantic distinction which can be stated in terms of relative time-stability. Encoding in the nominative refers to situations which are relatively stable in time and unlikely to change, since oblique encoding emphasises the fleeting or temporary nature of the situation. The nominative-oblique switch is typical of north-eastern Europe and is one of the features of the Circum-Baltic languages (also referred to as the Baltic Sprachbund, Dahl \& Koptjevskaja-Tamm 2001: 624). The Erzya nominal and adjectival predicates of 'be' copula constructions display such double encoding taking the form of a nominativeoblique case opposition, and in Erzya this oblique case is the transitive.

Stassen (2001) summarises that in the Circum-Baltic languages the employment of the nominative indicates class membership which is in some way an essential and permanent feature of the subject. Temporary, contingent or non-essential properties or class membership are encoded with the translative and essive cases (Finnic languages) or instrumental (Lithuanian, Russian, Polish). In the Slavic languages of the area, however, time-stability does not play a major role, but rather the switch is conditioned by many formal, semantic and stylistic factors (see below Section 5.2). The Mordvin languages are not included in Stassen's study of the nominative-oblique switch.

A kind of nominative-oblique switch similar to that occurring in Erzya in class membership and property predication is characteristic of Russian. It has been sug- 
gested that the extension of the translative into $u l^{\prime}\left(n^{\prime}\right)$ ems copula constructions is due to Russian influence (Bartens 1996: 29). A reanalysis and extension of case suffixes based on language contact has occurred in Southern Veps and Livonian, as Grünthal (2003: 204-205) suggests. This contact-induced change was based on morphosyntactic similarities between the inflectional cases of Southern Veps and Russian, and Livonian and Latvian respectively. In the following, my aim is to place the Erzya patterns among the patterns of the other languages in the area. Finally, I will also compare Erzya and Russian data in order to reveal the similarities and differences between the constructions of the two languages.

\section{I. The Finnic nominative-translative-essive switch}

As regards the encoding of class membership and property predication suggested by Kont (1955), Finnic can be divided into northern and southern groups. Similarly to the Mordvin languages, the southern group, to which most Estonian dialects, Livonian and Veps belong, displays a nominative-translative switch. The nominative refers to the permanent or time-stable nature of the reference, since the translative emphasises the temporary nature of the situation. The translative case is employed to encode both dynamic and stative functions (see also Riese 1993). Figure 1 illustrates this switch, with examples from Estonian cited from Pai $(2001: 243,239){ }^{3}$

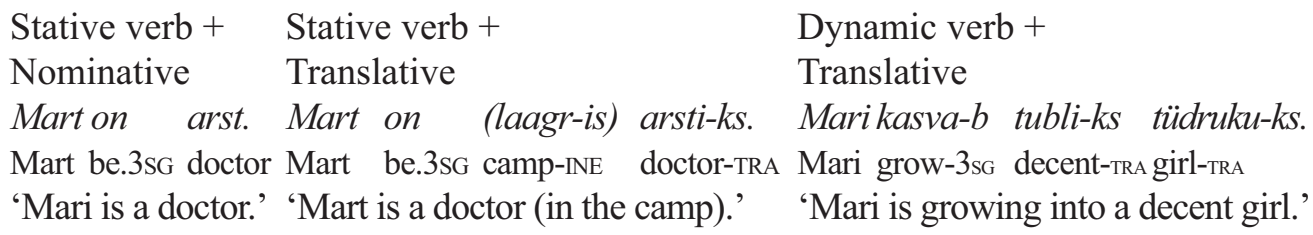

Time-stable $\quad$ Less time-stable

Figure I.Time-stability constraining the switch between the nominative and the translative with examples from Estonian.

In the northern group of the Finnic languages (as defined by Kont), ${ }^{4}$ which consists of Finnish, Karelian, Ingrian and Vote (as well as, to some extent, Standard Estonian) the translative and essive cases switch with the nominative case. The translative occurs in constructions that are employed to encode dynamic relations, while the essive occurs in those encoding stative relations which are prone to change or temporary.

3 The whole system of Estonian is more complex, since the essive case switches with the translative case in stative relation clauses. However, the essive is a relatively new case in Standard Estonian and its use is restricted (Erelt \& Metslang 2003; Pai 2001).

4 It should be observed that a division of this kind into northern and southern groups is relevant only with regard to the encoding of the nouns and adjectives in these clause types. 
The clauses in which the essive occurs contain the time dimension, since the state is valid at the particular moment. The nominative encoding makes reference without the time dimension. (See ISK 1206-1208 for Finnish.) Figure 2 illustrates the switch using Finnish examples.

\begin{tabular}{lll} 
Stative verb + Nominative & Stative verb + Essive & \multicolumn{2}{l}{ Dynamic verb + Translative } \\
Ole- $n$ opettaja. & Ole- $n$ opettaja-na. & Tule- $n$ iloise-ksi. \\
be-1sG teacher & be-1sG teacher-Ess & become-1sg glad-TRA \\
'I am a teacher.' & 'I am a teacher (now).' 'I become glad.'
\end{tabular}

without time dimension contemporary state change of state

Figure 2. The nominative-essive-translative switch in Finnish

In Finnish the stative copula verb olla is cognate with the Erzya $u l^{\prime}\left({ }^{\prime}\right) e m s$ copula that etymologically bears the frequentative suffix -ne-. The Finnish copula occurs together with a nominal predicate inflected in the essive case, and the Finnish translative does not occur in copula constructions. ${ }^{5}$ Furthermore, the essive case does not occur with dynamic verbs, but in dynamic constructions the translative case is employed. It is not accidental that in Figure 2 the dynamic construction has, as an example, a clause with the translative encoded adjective iloinen 'glad' instead of the noun opettaja 'teacher'. Another construction type would be used in the dynamic expression 'I become a teacher'. It is not in the scope of the present study to illuminate the factors in operation in Finnish, for further information see ISK (860-861).

The translative case *-kse is of common origin in the Finnic and Mordvin languages. There are two theories regarding the origin of the suffix (Zaicz 1998: 193194). First, it has been suggested that the translative arose from two old lative suffixes *-k and *-s (e.g. Bereczki 1988: 323; Riese 1993: 5). Creissels (2011) suggests, on the basis of cross-linguistic data, two possible grammaticalization paths from participant role markers to functive markers (among which the Finnic-Mordvin translative belongs, see above). The first path is locative $>$ functive, and the second is lative $>$ transformative $>$ functive. He states correctly that a grammaticalization path locative $>$ functive can be safely reconstructed for Finnish in the case of the grammaticalization of the essive $-n A$. He includes also the grammaticalization of *-kse in this type. However, the grammaticalization path lative $>$ transformative $>$ functive cannot be safely reconstructed for Mordvin. Namely, the development of the translative case might rather be related to a denominal derivational suffix that is exactly identical in form (Saarinen 2001: 245). This derivational suffix occurs in the Finnic, Mordvin, Saami and Samoyed languages and therefore is of ancient origin (Aikio \& Ylikoski 2007: 58; Janhunen 1989: 301). According to Janhunen (ibid.) it is even possible that

5 Except for some specific construction types, see (ISK 1207). 
the translative case existed already in Proto-Uralic. The developmental path derivational suffix > inflectional suffix is plausible also in the light of the fact that the difference between derivational and inflectional suffixes in the Finno-Ugric languages may be quantitative rather than qualitative, and there are examples of derivational suffixes having become inflectional (e.g. Janhunen ibid.; Laakso 2005: 102). Furthermore, as Kont (1955: 164) notes, the Mordvin translative $-k s$ has neither lative nor locational functions, and as illustrated above, in many Finnic languages the translative encodes also stative relations.

\subsection{Nominative-instrumental switch in Russian}

Russian displays double encoding of nominal and adjectival predicates in the form of a nominative-instrumental switch. This switch differs in many respects from that attested in the Finnic languages. Unfortunately, it is not within the scope of this study to examine the Russian switch in depth, but readers interested in it should look to the excellent description made by Johanna Nichols (1981). In brief, in Russian the switch is generally not attested in present tense clauses, in which the predication pattern is a zero strategy (juxtaposition without any copulative elements) and the predicate nouns and adjectives are encoded in the nominative. This kind of nominal predicate construction is identical with those attested in many Finno-Ugric languages, see Turunen (2010b). When the predicate nouns and adjectives occur in a construction with the copula verb byt 'be' in tenses other than the present, both nominative and instrumental encoding become possible. The choice between the nominal and instrumental cases is governed by various formal, semantic, lexical, constructional and stylistic factors. Among these factors, for example, the lexico-semantic class of the predicate affects encoding. Predicate nouns of occupation are usually inflected in the instrumental, as illustrated in Example (8). (Nichols 1981: 85-86, 140-182.)

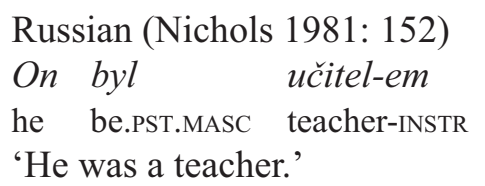

Stassen (2001: 588) concludes on the basis of Nichols (ibid.) that, unlike the Finnic languages, time-stability does not play a major role in Russian. Timberlake (2004: 288) summarises the issue by writing, "...with nouns, the instrumental is used when there is any hint of limiting the state in time-worlds or any concern with defining an individual - of indicating that this individual, not others, fits into a certain definition." More examples from Russian are provided below when a comparison is made between the original Russian sentences and their Erzya translations. 


\section{Functions of the Erzya translative in Subject NP + 'be'-copula + NP constructions}

The Erzya translative is employed to refer to being something, similarity to something, change to something or mood of doing something (Cygankin et al. 2000: 86-87; Koliadenkov 1954: 153-154; Bartens 1999: 98-99). Translative encoded nouns do occur in constructions with full semantic verbs, but the present treatise concentrates on the semantics of the Erzya translative only in constructions which denote the stative relationship of being. In these constructions the translative encoded noun expresses being similar to something, as illustrated in Example (9), and being good/suitable for something, as illustrated in Example (10). The translative also occurs in stative expressions in the function of to be in language $X$, as illustrated in Example (11).

(9) Mon varma-ks, bod'aj.

$1 \mathrm{SG} \quad$ wind-TRA grandfather

(Kliuchagin 1997: 53)

'I am like the wind, grandfather.'

(10) T'e kocto-ś platija-ks.

this material-DEF cloth-TRA

(Svetlana Motorkina, p.c.)

'This material is good for a cloth.'

(11) Ruz-ks elí eŕźa-ks siń?

Russian-TRA or Erzya-TRA 3PL

(Siatko 2003: 10)

'Are they [books] in Russian or Erzya?'

These constructions resemble clauses denoting class membership or property in that they are coded in the present tense zero, as illustrated in Examples 8-10. They differ from the nonverbal predicate clauses illustrated in Examples (1-6) above in that the translative encoding cannot be omitted without considerable change in the denotation of the clause. Translative encoding prevents the employment of the predicative suffix construction, which occurs in nominal and adjectival predication in 1st and 2nd person subject constructions. The encoding of the clause in Example (9) could thus not be made using the inflectional first person marker. A translative coded noun expressing the point of comparison may also occur as a free complement in a nominal predicate construction, like umarinaks in Example (12). In Example (12) the predicates, namely the noun cvetat and the adjective odat, are encoded using the predicative suffix construction.

(12) Umarina-ks ton cveta-t, od-at. (Siatko 2003: 4) apple.tree-TRA 2SG flower-2SG young-2SG 'Like an apple tree you are a flower, you are young.' 
As with the present tense clauses illustrated in Examples (8-11), in the following past tense clauses, Examples (12-15), the translative function is also quite obvious, and it cannot be omitted without a radical change in the semantics of the construction. In this instance the relationship between the subject NP and the translative encoded NP differs from those clauses in which both NPs are in the nominative. When the predicate NP is in the translative, the referents of the two NPs are similar to each other, as in Examples (13) and (14). In Example (14) the first clause is structured with an $u l^{\prime}\left(n^{\prime}\right)$ ems copula and similarity is expressed using the translative, while the second clause contains the dynamic verb tejevems 'change into something', which triggers the translative.

(13) T'eta-nzo marto vasto-vo-ma-ś

father-3SG with meet-REFL-VN-DEF

ul'ne-ś ténze ińeči-ks.

(Siatko 2003: 4)

be-1PST.3SG ALL-3SG Easter-TRA

'Meeting his father was like Easter to him.'

(14) Ul'n-i-ńek kolmo-će Rime-ks, teje-v-i-ńek

be-1PST-1PL three-ORD Rome-TRA change-REFL-1PST-1PL

Sodomo-ks di Gomorra-ks...

Sodom-TRA and Gomorrah-TRA

(Doronin 1996: 239)

'We were like the Third Rome, we changed into Sodom and Gomorrah.'

The translative encoding also occurs in a quite different function in clauses such as Example (15). The employment of the translative emphasises a non-literal reading.

(15) Paŕak, son ul'ne-ś=kak

maybe (s)he be-1Pst. $3 \mathrm{sg}=$ too

éramo-ń vaśeńće eskelkse-ks?

life-GEN first step-TRA

(Siatko 2003: 3)

'Was it perhaps the first step of his life?'

Example (16) contains two clauses with translative encoding. The first clause in Example (16) expresses the status of the subject, which lasted for a long time. This example illustrates the function of the translative, which is to express being something temporarily. Also, Example (17) refers to a temporary relationship, but a temporary relationship more obvious than in (16). The function of the translative in the constructions presented in the second clause of Examples (16), Example (18) and (19) is either that of similarity, or a temporary relationship. Omission of the translative is not possible in (18) and (19) without a radical change in meaning. Similar constructions are employed in Estonian, as illustrated in Example (20). 
(16) Kuvat' ulńe-ś mastoro-ń vet-ije-ks di

long.time be-1PST.3sG country-GEN lead-PTCP.PRS-TRA and

Paz-ńeń ozń-ića-t'ńe-ńn teta-ks.

(Doronin 1996: 437)

God-ALL pray-PTCP.PRS-PL-DEF-GEN father-TRA

'He was the leader of the country for a long time and like a father to those who pray to God.'

(17) Ošo-ń-t ńevt'ića jalga-ks ulńe-ś

town-GEN- DEF show-PTCP.PRS friend-TRA be-1PST.3SG

eŕźa-ń sodaviks poet.

(Siatko 2003: 2)

Erzya-GEN famous poet

'A famous Erzya poet was used as a guide to show the town.'

(18) miń tink turtov ulń-i-ńek

1PL 2PL.GEN for be-1PST-1PL

téta-ks=kak, ava-ks-kak.

(Paltin \& al. 1997: 32)

father-TRA $=$ too mother-TRA $=$ too

'for you we were also a father and mother.'

(19) ...,teta-ks ul'́n-i-t' moń-eń.

father-TRA be-1PST-2SG 1sG-ALL

(Kliuchagin 1997: 76)

'You were like a father to me.'

Estonian

(20) Ta ol-i mei-le ema-ks.

(Pai 2001: 244)

3SG be-PST.3Sg 1PL-ALL mother-TRA

'She was a mother to us.'

The basic function of the Erzya translative in copula constructions is to encode similarity with the referent of the subject NP, or temporary relationship. As similarity is not encoded in the constructions by any other formal means than translative encoding in the predicate adverbial, the temporality of the relationship is often manifested by adverbs of time such as in Example (16) kuvat' 'long time'. It is plausible that in these cases the whole construction bears the semantic content of unstability.

\section{Factors conditioning the employment of the semantically vague translative}

In the construction types directly illustrated in Examples (8-18) the translative encoding has a clear semantic function. In most cases, if it was replaced by the nominative, the meaning of the clause would change, or the reading of the clause would depend more on the context. As stated in the Introduction, the translative encoding in the con- 
struction type occurring in Example (6) does not seem to bear clear semantic content and could be omitted. Consequently, there are constructions in Erzya of the type subject NP $+u l^{\prime}(\dot{n})$ ems copula + predicate NP which express stative relations and in which the noun functioning as the semantic predicate of the clause can be encoded either in the nominative or the translative. In the following, I examine those clauses which resemble the one illustrated in Example (6). From now on, to distinguish these semantically more vague translatives from the translative expressing similarity, being good for something or being in language $X$, I shall use the term semantically vague translative. It is assumed that the translative encoding is dependent on the time-stability factor, but because there may also be other factors, I have chosen this as a cover term. In the following, my aim is to clarify the semantics and functions of translative encoding in those construction types in which translative encoding is less easily explained.

\section{I. Tense and time-stability}

As the examples in Section 4 illustrate, the semantically vague translative occurs in nominal and adjectival predicate constructions which contain the copula verb $u l^{\prime}(\dot{n})$ ems. These constructions refer to the past or future, and express relations such as class membership and property. Importantly, non-present tense constructions express relations that are no longer valid, or not yet valid, that is, the state of the referent of the subject NP has either changed or will change. In referring to the past tense, inflection with the copula is sufficient and translative encoding is unnecessary, as illustrated in Example (5). The employment of an inflected copula in the present tense on its own also refers to the future, and translative encoding of the noun is not obligatory.

Even though the semantically vague translative usually does not otherwise occur in nonverbal predicate constructions, which refer to a state which is valid in the present tense, there was, however, one exception in my database, illustrated in Example (21). In this clause, the noun expressing the status of the subject is declined in the translative. Importantly, the clause does not in the first place identify Yeleozar with the leader of place $X$, but rather reports that there has been a change in leadership, and at the moment (perhaps also temporarily), the leader is Jeleozar. When Example (21) was discussed with Nina Kazaeva and Svetlana Motorkina, they found that the employment of the translative is related to the presence of nej 'now'.

$$
\begin{array}{llll}
\text { To-so-ń } & \text { pŕavto-ks } & \text { ńej Jeleozar shimńike-ś. } \\
\text { that-INE-GEN } & \text { director-TRA } & \text { now Jeleozar } & \text { Skhimnik-DEF }
\end{array}
$$

'The leader of that place is now Jeleozar, the Skhimnik.' 6

(Doronin 1996: 71)

Stassen's universal (see Section 5) suggests that the nominative-oblique switch is related to time-stability. This universal predicts that the translative encoding in these

The highest monastic order, Monk of the Great Schema, in Russian Skhimnik. 
clause types should refer to less time-table, temporary or contingent relations. Thus it is to be expected that the translative will not occur in clauses referring to general truths without a dimension in time. The occurrence of the translative in Example (21) may be related to the difference between identificational statements and class-membership predications. Identificational statements do not usually make reference to time (as identity is a rather stable feature), whereas class-membership predication may report a state that is more prone to change. Example (22) illustrates that the translative is possible in Erzya even though a past tense construction refers to a relatively stable state, as the expression pingenze pert' 'all his life' implies.

\section{(22)}

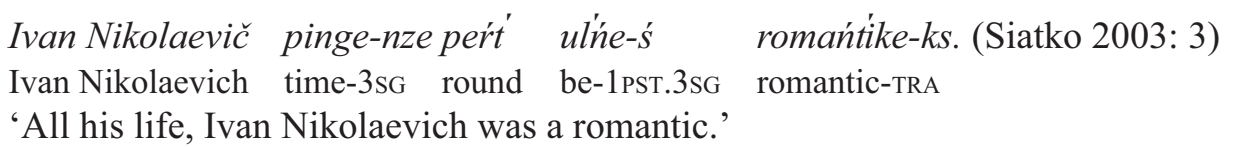

In Erzya there are also morphological constraints which prevent the translative in identificational sentences. The predicate nouns of identificational sentences are usually definite, while also being morphologically marked for definiteness. The definite declension of Erzya nouns does not contain a translative, neither can the translative attach to possessive suffixes. A further reason for neglecting the translative in identificational statements may be that the translative has the function of referring to being similar to something which semantically conflicts with identificational predication ('someone is like something' vs. 'someone is something').

Nevertheless, translative encoding is also possible in identificational statements, as Examples (22-24) illustrate. Identificational statements usually report stable states. As translative encoding in identificational statements is possible in Erzya too, timestability seems not to be a decisive factor constraining the nominative-translative switch in Erzya. This makes Erzya a counterexample to Stassen's hypothesis presented above. Thus, I think it possible that the choice of the translative is not dependent on time-stability, but other complex factors such as word order and the number of optional arguments. In order to study the other factors, more data should be collected. In Example (23) the second clause is identificational and the nominal predicate ejkakšoks is inflected in the translative. Then, Example (24) presents an identificational statement in which the translative-inflected predicate is a name. The second phrase in Example (25) is also identificational. According to Svetlana Motorkina (p.c.), translative encoding is obligatory in (24) because the subject is the third person pronoun son.
Ańśak vejke
only one
zijano-ś:
ćora-ś
ulńe-ś
ved'-azoro-ń
problem-DEF man-DEF
be-1PST.3SG
water lord-GEN one-DIM child-TRA
(Siatko 2003: 10)
'There was only one problem: the man was the only child of the lord of the wa- ters.' 
(24) Son Viŕaska-ks ulńe-ś.

(Siatko 2003: 3)

3SG Viryaska-TRA be-1PST.3SG

'He was Viryaska.'

(25) Vaśńa, kela, son ulńe-ś prostoj lomańe-ksfirst reputedly $3 \mathrm{SG}$ be-1PST.3SG simple human-TRA d'eva Marija-ń ćora-ks.

(Doronin 1996: 55) virgin Mary-GEN son-TRA

'They say that first he was just a simple human being, the son of the Virgin Mary.'

Above, Example (7) shows the copula verb ulems referring to the future (Cygankin et al. 2000: 164). Kangasmaa-Minn (1993: 76-77) discusses the Permic languages and Hungarian, noting that when a copula verb of existence is employed to refer to the future, it has a double function: as a copula of static nominal predications it places the situation in the future, but in dynamic sentences it indicates a change. Similarly, in Erzya ulems has the stative rendering 'be something in the future' and the dynamic rendering 'become'. The employment of the translative emphasises the dynamic nature of the relationship. In this respect these constructions resemble those in which there occur other semantically full dynamic verbs expressing changes in state, such as vel'avtovoms 'change', tejevems 'change' or arams 'become, change'. Further, these verbs trigger the translative. The presence of the translative in ulems copula constructions is not obligatory, but translative encoding does occur in most of the clauses in my data from standard written Erzya. Some of these clauses are illustrated in (25-27), in which the nonverbal predicates ćoraks, kilejńeks and prośtaźeks are in the translative. In Example (29) the adjective vačo is in the nominative.

(26) Buti meke-v vel'avt-i,

if back-LAT return-3SG

ton uš pokš ćora-ks ul'-at.

2SG already big man-TRA be-2SG

(Siatko 2003: 4)

'When she comes back, you will already be a big man.'

(27) Mon-ś ara-n jutkozo-nk,

1SG-REFL will.be-1sG among-2PL

ul'an kilejéne-ks,...

(Siatko 2003: 10)

will.be-1SG birch-DIM-TRA

'I will be among you, I shall be a birch.'

(28) S'este prośtaźe-ks ul'-an.

(Siatko 2003: 10)

then forgiving-TRA be-1SG

'Then I shall be forgiving.' 
(29) Sonze marto vačo a ul'-at.

(Siatko 2003: 4)

3SG.GEN with hungry NEG be-2SG

'With him/her you will not be hungry.'

\subsection{Differences between nominal and adjectival predicates}

In Standard Erzya there is variation between the nominative and translative in nominal predicates especially, but adjectival predicates are more often found in the nominative in my data. Thus the part of speech affects the employment of the translative: it rarely occurs when the predicate is an adjective. In the written data, the translative was used in past tense adjectival predicate clauses structured with the $u l^{\prime}(\hat{n}) e m s$ copula four times, as illustrated in Examples (29-31). In comparison, the nominative occurred in 77 of a total of 91 constructions.

Most probably there are factors other than time-stability that influence the case marking. These factors may be related to the structure of the clauses, such as the number of optional arguments. The translative could simply be omitted from (30) and (31) and replaced by the definite marking as in (32). The clause in (30) refers to a specific situation and exemplifies a temporary state, but the clauses in (31) and (32) do not make reference to the time dimension. If the reading makes reference to the age of the referent of the subject NP, there is no possibility at all of a change.

(30) Kandolaz-t-ne-se purna-ź-sérna-ź

coffin-PL-DEF-INE gather-PTCP.PST-prepare-PTCP.PST

Olábaba ulńe-ś pek mazije-ks (Kliuchagin 1997: 77).

Olya granny be-1PST.3SG very beautiful-TRA

'Dressed up in the coffin, grandma Olya was very beautiful.'

(31) saldirkse-ś ava-ń turtov

saltcellar-DEF mother-GEN for

ul'ne-ś pek pitńeje-ks.

(Paltin \& al. 1997: 60)

be-1PST.3SG very precious-TRA

'The salt cellar was very precious to mother.'

(32) Maksim ul'́ne-ś śemija-so-ńt' śehte pokšo-ks,..

Maksim be-1PST.3Sg family-INE-DEF SUP big-TRA

'Maksim was the biggest in the family.'

The data of the present study presents many genres, and there are also recorded discussions, see Section 2. In the discussions, the adjectival predicates were never encoded in the translative in corresponding constructions. The questionnaire data, which consisted of translations from Russian to Erzya, provided some examples in which adjectives were inflected in the translative, but mostly the adjectives were in the nominative 
case in the questionnaires too. In the original Russian sentence of Example (33), the predicate NP is an adjective in the nominative. All of the Erzya sentences contained an adjective encoded in the nominative as well, as illustrated in Example (34).

Russian (questionnaires)

(33) Pogoda byla khorosh-aia.

weather be.PST-FEM good-FEM

'The weather was good.'

Erzya (questionnaires)

(34) Ǔ́o-ś ulńe-ś mazij.

weather-DEF be-1PST.3SG beautiful

'The weather was beautiful.'

The original Russian sentence shown in Example (35) contained an adjective in the nominative, even though this adjective could have been inflected in the instrumental. The sentence was translated into Erzya with a construction type in which the predicate adjective was in the nominative 14 times. Two informants out of 16 used a construction with the adjective inflected in the translative, as illustrated in Example (36). (Among the Mokshas, seven informants of a total of eight used the nominative and one the translative.)

Russian (questionnaires)

(35) Ty tozhe byla krasiv-aia.
2sG also be.PST-FEM beautiful-FEM
'You were also beautiful.'

Erzya (questionnaires)

(36) $T o n=g a k$ ulń-i-t mazij-ks.

$2 \mathrm{SG}=$ too be-1PST-2SG beautiful-TRA

'You were also beautiful.'

It is relevant to add that even though adjectives were not inflected in the translative during the free conversations (vernacular data, see Section 2), translative-inflected adjectives were used by informants when the interviewer asked the informants to translate from Russian. The informants then produced sentences of the kind illustrated by Example (37).

(37) Ton ul'n-i-t odo-ks.

2SG be-1PST-2SG young-TRA

'You were young.' 
Finally, it must be noted that even though adjectival predicates were seldom inflected in the translative in the standard written data, the pro-adjectives iśtamo 'like that' (illustrated in Example 37), kodamo 'like what' and lija 'other kind' occurred in the translative relatively more frequently than adjectives. Encoding in the translative may be also related to style, in those cases in which there is a construction with a translative-inflected adjective/pronoun in a close context. In Example (39) the pronoun kodamoks could be encoded in the nominative as well, but in the following phrase, kadovoms triggers the obligatory encoding of iśtamoks in the translative, which may have affected the encoding of the previous phrase.

(38) Son ikele-jak ulńe-ś iśtamo-ks.

(Paltin et al. 1997: 64)

$3 \mathrm{SG}$ before=too be-1PST.3SG like.that-TRA

'(S)he was also like that earlier.'

(39) Ton kije? Kodamo-ks ul'n-i-t',

2SG who like.what-TRA be-1PST-2SG

iśtamo-ks kadov-i-t.'

(Kliuchagin 1997: 26)

like.that-TRA stay-1PST-2SG

'Who are you? Whatever you were like, as such you have remained.'

Kangasmaa-Minn (1993: 79) notes that in the Finno-Ugric languages declined adjectives are rather rare, and among the Finnic languages the inflected adjective complement is more conventional in Finnish (see also Pajunen 1999, Section 5.1). As adjectives do not decline to the same extent as nouns generally in the Finno-Ugric languages, it is to be expected that they are not encoded in the translative as extensively as nouns. However, as my data suggests, translative encoding of adjectives is possible in Erzya. Also, a participle may be inflected in the translative in Erzya, see Examples (15a) and (1). As Bartens (1999: 99) illustrates, when the predicate is inflected using the present participle $-i$, the translative case can also occur in clauses which refer to the present, and furthermore, the translative-inflected participle may be inflected according to person. Structures of this kind only occur in my folklore data (see MV II 44).

\subsection{Nouns of occupation}

In the standard written data, amongst those clauses which denote class membership, translative encoded nouns occurred especially among those nouns denoting occupation. As was noted above, in Russian the lexico-semantic class of occupation nouns is obligatorily inflected in the instrumental in this construction type, as illustrated in Example (8). The following clauses illustrate that lexemes of occupation are often, although not necessarily, borrowed from Russian, as shown in Examples (39-41). In (42), only one of the occupation nouns, pravt, is not a Russian loan. Moreover, parti- 
ciples functioning as occupation nouns, as illustrated in Example (16) above, as well as derivations of old words such as pravt illustrated in Examples (41 and 42), occur in the translative case.

(40) Son ulńe-ś alkukso-ń ribako-ks.

(Erkay 1991: 167)

3SG be-1PST.3SG real-GEN fisherman-TRA

'He was a real fisherman.'

(41) Mińek litératura-ńt mala-v veśe ušod-ića-t'ńe

1 PL.GEN literature-DEF.GEN close-LAT all begin-PTCP.PRS-PL-DEF

juta-ś- $t$ žurnalistika-ń škola: ulńe-śs- $t$

go-1PST-3PL journalism-GEN school be-1PST-3PL

koŕrespond'ente-ks, litsotrudńike-ks, redaktor-ks.

(Siatko 4: 171)

correspondent-TRA collaborator-TRA redactor-TRA

'Almost all our beginners in literature went to the school of journalism: they were correspondents, collaborators, editors.'

(42) Ulíe-ś kolhoz-oń pŕavto-ks, zavhozo-ks,

be-1PST.3SG kolkhoz-GEN director-TRA leader-TRA

kiŕpeć-eń teje-ma-ń koŕas maśtére-ks,

brick-GEN make-VN-GEN about master-TRA

škola-so trudo-ń učitel'e-ks, bibliotékaŕe-ks...

(Siatko 2003: 2)

school-INE work-GEN teacher-TRA librarian-TRA

'He was the director of a kolkhoz, a manager, a master at making bricks, at school a handicraft teacher, librarian...'

(43) Lazaŕ-eń son ikele-jak sod-ilí-ze, śe Romanov oš-so

L.-ACC $3 \mathrm{SG}$ before $=$ too know-2PST-3SG $>3 \mathrm{SG}$ it $\mathrm{R}$

town-INE

monastire-ń pravto-ks ulńe-ś.

monastery-GEN director-TRA be-1PST.3SG

(Doronin 1996: 413)

'He knew Lazar even earlier; he was an archimandrite in the town of Romanov.'

The following clauses denoting occupation share the same characteristic: they make reference to a specific point in time. The clause in Example (44) includes the adverb kuvat' 'for a long time', while in Example (45) we find the adverb ikele 'before, earlier', in Example (46) vojnado ikele 'before the war' and in Example (47) kodgemeńće ijetńeste 'in the sixties'. These clauses refer to the temporary nature of the states. In Example (48) the expression vojnado ikelejak makes reference not only to a specific point in the past, but also to the fact that the referent of the subject is still functioning in the same occupation. 
(44) Kuvat' ulńe-śs monaho-ks.

long.time be-1PST.3SG monk-TRA

(Doronin 1996: 207)

'He was a monk for a long time.'

(45) Ikelé son ul'́e-śs patriarho-ks,

before 3sg be-1PST.3sg patriarch-TRA

ńej-raužo monah.

(Doronin 1996: 455)

now black monk

'Earlier he was a patriarch, now he is a black monk.'

(46) Vojna-do ikele Kelu vele-ń vejkécora

war-ABL before Kelu village-GEN one man

ulńe-ś Moskov-so metro-ń inžeńeré-ks.

(Siatko 2003: 2)

be-1PST.3Sg Moscow-INE metro-GEN engineer-TRA

'Before the war, a certain man in the village of Kelu was a metro engineer in Moscow.'

(47) Kodgemeń-će ije-t'-ńe-ste té lomańe-śs ulñe-śs

sixty-ORD year-PL-DEF-ELA this man-DEF be-1PST.3SG

Kongo-ń vaśeńće mińistra-ks.

(Siatko 2: 35)

Congo-gen first minister-TRA

'In the sixties this man was the prime minister of the Congo.'

(48) ... sinst direktor-oś vojna-do ikele-jak

they.GEN director-DEF war-ABL before=too

ul'ne-śs učitelée-ks.

(Erkay 1991: 143)

be-1PST.3Sg teacher-TRA

'Their director was a teacher before the war as well.'

In Example (49) reference is made to a specific place, and thus to the temporary nature of the event. Example (50) contains a temporal adverb, but the expression sval 'always' refers to a stable situation. The basic word order in Erzya nominal predicate constructions is Subject NP-Copula-Predicate NP. The word order in Erzya is free, thus the translative inflected predicate noun may precede the copula, as in Examples $(48-49)$.

(49) ... ofićeŕe-ks toso ulńe-ś.

(Siatko 2003: 2)

officer-TRA there be-1PST.3SG

'He was an officer there.'

(50) Žurnaliste-ks son sval ulńe-ś.

(Siatko 2003: 10)

Journalist-TRA 3sg always be-1PST.3sg

'She had always been a journalist.' 
In my data there are also clauses in which the Russian loanword denoting occupation is in the nominative, as in Example (51). In the clauses presented in Examples (51) and (52), the noun of occupation is in the nominative and the examples do not contain any reference to a specific point in time. If translative encoding is not employed, the predication pattern may also be a synthetic one, as illustrated in the second clause of Example (52), in which the predicate noun kapitan 'captain' is conjugated in the third person singular of the second past tense.

(51) Son tur-ś

Zapadnoj front-so,

$3 \mathrm{SG}$ fight-1PST.3SG western front-INE

ulńe-ś štabs-kapitan.

(Kliuchagin 1997: 41)

be-1PST.3sG headquarter.captain

'He fought on the western front; he was a headquarter captain.'

(52) Sańa l'ela-ś-

aŕtill'erist ulńe-ś,

S. big.brother-DEF gunner be-1PST.3sG

maštov-s Berlin-se maje-ń kavkso-će či-ste,

die-1PST.3SG Berlin-INE May-GEN eight-ORD day-ELA

kapitan-ol.

(Siatko 2003: 2)

captain-2PST.3SG

'His/her big brother Sanya was a gunner. He died in Berlin on the 8th of May and was a captain.'

\subsection{Translative encoding and negation}

The negation of Erzya stative relation clauses is extremely complex (for a summary see Hamari 2007: 247; Turunen 2011). There are two different negators, $a$ and avol,' in present tense nominal and adjectival predicate constructions. In the past tense one possibility is to inflect the nominal/adjectival predicate using the past tense predicative suffix together with either of the negators $a$ or $a v o l$. If the copula construction is employed, the negation particles $a$ and avol'occur as constituent negators, as illustrated in Example (53), in which the predicate noun is in the translative.

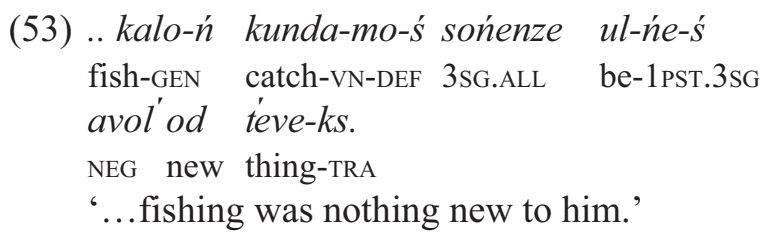

It is also possible to use a similar past tense negation pattern with verbal predicates, in which case the negative auxiliary ez- occurs with the connegative form of the copula 'be'. This type was infrequent in my database, and in the database of Hamari (2007: 
130) as well. Example (54) illustrates this type with translative encoded present tense participles.

(54) Ańśak źardo=jak eź-i-ń ul'ne lavg-ića-ks only when=too NEG-PST-1SG be.CNG babble-PTCP.PRS-TRA di eś mastoro-ń mij-ića-ks. and own country-GEN sell-PTCP.PRS-TRA

'Just that I was neither a babbler, nor a seller of my own country.'

If the noun is inflected in the translative, there will be one further possibility, which is not attested in those constructions where the nominal and adjectival predicates are in the nominative. This would be to employ the locational-existential-possessive negator araś. The employment of the negator araś connects translative encoded predicates with locational predicates. Use of this construction type (Subject + araś-PST-PX + Predicate NP+TRA) is not frequent, since I only found three clauses with this pattern, and in Hamari's data there was just one occurrence (Hamari 2007: 240-241). In (55) the predicate is a noun, in (56) a pronoun inflected in the translative.

(55) Uŕe-ks źardo-jak araś-eli-ńek di a karma-tano! (Doronin 1996: 427) slave-TRA when=too NEG-2PST-1PL and NEG begin-1PL

'We were not slaves, and never will be!'

(56) Vaj, ava-kaj, di mon od-sto=jak

oh mother-voc and 1sG young-ELA=too

iśtamo-ks araś-el'-iń!

(Doronin 1996: 186)

like.that-TRA NEG-PST-1SG

'Oh mother, I was not like that, not even when I was young!'

The questionnaires contained one negative sentence with an adjectival predicate. In the Russian original of this sentence, the adjectival predicate was encoded in the instrumental (as negation triggers the instrumental in Russian), as illustrated in Example (57). The translative occurred in 4 out of 16 Erzya clauses, Examples (58) and (59). In one of these, the negator araś was employed, as illustrated in Example (58), and in two clauses the copula verb with the constituent negator $a$, as in Example (59).

Russian (questionnaires)

Ia tozhe ne byl-a nekrasiv-ym
1SG also NEG be. PST-FEM.3SG unbeautiful-INSTR in
'Yet I was not bad looking when I was young.'


Erzya (questionnaires)

(58) Od-sto mon araś-eli-ń $\quad$ a $\quad$ mazij-ks.
young-ELA 1SG NEG-2PST-1SG NEG beautiful-TRA
'I was not bad looking when I was young.'

(59) Mon tožo ul'-ń-i-ń a mazij-ks od-sto.

$1 \mathrm{SG}$ also be-1PST.1SG NEG beautiful-TRA young-ELA

'Yet I was not bad looking when I was young.'

Interestingly, the translative occurred in 5 out of 8 Moksha clauses. The relatively frequent occurrence of translative encoding in Moksha could be due to Russian influence, occurring mainly in translations. The effect of collecting data through questionnaires containing translations is discussed in Section 6.

\section{Comparison of Erzya translative and Russian instrumental constructions in questionnaire data}

The questionnaire data (see Section 2) provides a point of comparison between Erzya and Russian patterns, and it hints that further investigation could be fruitful. Translative encoding was relatively frequent in the questionnaires consisting of translations from Russian to Erzya. There were eight clauses in the questionnaires that had a past denotation. In the first questionnaire there were six clauses translated by 24 Erzya students, while in the second there were two clauses translated by 16 Erzya students. All of these past tense clauses, a total of 170 clauses, were translated with the past tense copula verb, and the other possible predication pattern, the predicative suffix construction illustrated in Example (4) above, was not used. Erzya nominal predicates were almost always inflected in the translative when the original Russian clause contained an instrumental: in only 6 out of 170 clauses did a nominative occur in place of a translative. The questionnaires contained only nouns inflected in the instrumental, and they did not contain Russian sentences in which an adjectival predicate was encoded in the instrumental. As illustrated in Example (36), the adjectives did occur in the translative in the questionnaires in that sentence type where the Russian instrumental would have been possible. As far as adjectives are concerned, this data is naturally insufficient to make a generalization.

The following examples illustrate the correspondence between the Erzya translative and the Russian instrumental encoding. The nominal predicates of Russian sentences are in the instrumental and those in Erzya in the translative. In (61) the predicate noun is ejkakšsoks, in (63) lomańeks and in (65) aktrisaks, which is a Russian loan. In corresponding constructions the nominal predicates are more often in the nominative than in the translative in standard written Erzya, and in that case they agree in number (ejkakšst, lomań-t). 
Russian (questionnaires)

(1) Mybyl-i vesely-mi detishka-mi, vsegdaigra-li

1PL be.PST-PL glad-INSTR.PL child-INSTR.PL always play-PST.PL

'We were happy kids, we always played.'

Erzya (questionnaires)

(61) Miń ulń-i-ńek veśela ejkakšo-ks,pačk nalkś-i-ńek.

1PL be-1PST-1PL glad child-TRA through play-1PST-1PL

'We were happy kids, we always played.'

Russian (questionnaires)

(62) Moj-a babushka $i$ moj dedushka

$1 \mathrm{SG}-\mathrm{FEM}$ grandmother and my.MASC grandfather

byl-i bolshi-mi liud-mi v sele.

be big-INSTR.PL human- INSTR.PL in village.PRP

'My grandmother and grandfather were important people in the village.'

Erzya (questionnaires)

(63) Moń baba-m di d'eda-m

1SG.GEN grandmother-1sG and grandfather-1sG

ul'ńe-ś- $t$ pokš lomańe-ks vele-se.

be-1PST-3PL big human-TRA village-INE

'My grandmother and grandfather were important people in the village.'

Russian (questionnaires)

(64) Moi-a tetia byl-a izvestn-oj aktris-oj.

$1 \mathrm{SG}-\mathrm{FEM}$ aunt be.PST-FEM famous-INSTR actor-INSTR

'My aunt was a famous actress.'

Erzya (questionnaires)

(65) Moń pata-m ulńe-ś sodaviks aktrisa-ks/nalk-ića-ks.

1SG.GEN aunt-1sG be-1PST.3SG famous actor-TRA/play-PTCP.PRS-TRA

'My aunt was a famous actress.'

In the spoken-language data, translative encoding rarely occurred in nominal and adjectival predicate clauses. There was one occurrence in which a noun of occupation was in the translative, as illustrated in Example (66). The first clause has a past tense denotation with the nominal predicate lomań in the nominative as in the third clause of the same example, and the nominal predicate traktoristeks is inflected in the translative. 
(66) téta-m iśta žo paro lomań ulńe-ś,..

father-1sG also good human be-1PST.3sG

Son važod'śs kolhoz-so,

3SG work-1PST.3SG kolhoz-INE

ulńe-ś traktoriste-ks.

be-1PST.3sG tractorist-TRA

'My father was also a good man. He worked in the kolkhoz as a tractor driver.'

On the other hand, as noted above, translative encoding occurred in translations from Russian made during some of the interviews. When the informants were asked to translate Russian clauses, some of them used constructions such as (67), which never occurred in my other types of data.

(67) son ulńe-ś erźa-ks.

3SG be-1PST.3SG Erzya-TRA

'(S)he was an Erzya.'

The parallelism between Erzya and Russian patterns observed in translations is clear. The translative occurs most typically in translations from Russian into Erzya. It also occurs frequently in those constructions in which the lexeme is a Russian loan or, especially, a noun of occupation. Erzya participles which function as occupation nouns are also relatively often encoded in the translative. The semantically vague Erzya translative is frequently used in copula clauses which refer to the past tense or future, but it does not occur in those clauses that refer to the present tense. In this respect, the Erzya nominative-translative switch resembles the Russian nominative-instrumental switch. It is obvious, however, that the employment of the Erzya translative cannot be mapped together with the use of the Russian instrumental in a one-to-one correspondence. As noted above, employment of an oblique case is typical of the CircumBaltic languages, and as such, an areal phenomenon. Whether the employment of the translative in Erzya in the specific constructions types introduced above (the so-called semantically empty translative) arose through Russian influence is another matter. The similarity as well as the distinctiveness of the Erzya and Russian systems needs to be studied more in greater depth, and hopefully a comprehensive study of this matter will appear in the future.

\section{Discussion}

In Erzya translative encoding can be replaced with the nominative in some clause types of the structure [Subject NP + ul'(ń)ems copula + Predicate Noun/Adjective] without any change in the meaning of the clause. In the present treatise, the clear functions of the Erzya translative such as the one expressing similarity were left outside of the main discussion, and only that translative which switches with the nomina- 
tive in the previously mentioned construction type was taken into account. It was observed that this kind of translative encoding is dependent on the time reference of the constructions. The translative tends to occur in those constructions which make reference to a specific point in time in the past. The translative case, which is etymologically the same, is employed in similar constructions in the Finnic languages, especially in Estonian dialects, Livonian and Veps, in which the translative emphasises the temporality of relations. The difference between Finnic in general and Erzya is that in Erzya, translative encoding, when employed to refer to temporary relationships, occurs almost always in clauses which refer to the past tense and future events. This has to do with the fact that the copula occurs only in non-present nonverbal predicate clauses, and the employment of the semantically vague translative is dependent on the presence of the copula.

The future tense clauses in which the ulems copula is employed do not differentiate between a stative and dynamic interpretation. Consequently, the Erzya ulems copula construction type refers to a state in the future. In those constructions referring to the future, the noun may be in either the nominative or the translative.

Translative encoding is more frequent when the nonverbal predicate is a noun than when it is an adjective. Adjectival predicates can, however, be in the translative as well. The differences in the encoding of nouns and adjectives in predicate position are related to the discussion on part of speech distinctions in Erzya and the other Finno-Ugric languages. In Erzya, a distinction between nouns and adjectives is also made respecting the employment of predication strategies (see Turunen 2009).

Stated briefly, the Erzya data suggests that Stassen's (2001) generalization concerning time-stability and the nominative-oblique switch may not be as strong as he seems to suggest. Time-stability is definitely not the only factor constraining the occurrence of the translative in copula clauses, and translative encoding may occur also in identificational statements, which are stable in time. As noted above, timestability is not a very relevant factor in Slavic. In the translations from Russian to Erzya the translative case was employed relatively frequently. It is possible that the same complex semantic, lexical and stylistic factors that affect the nominative-instrumental switch in Russian affect the employment of the semantically vague translative in Erzya. The role of language contacts in the employment of the semantically vague translative ought to be studied in greater detail.

\begin{tabular}{llll}
\multicolumn{2}{l}{ Abbreviations } \\
1 & 1st person & DIM & diminutive \\
2 & 2nd person & ELA & elative \\
3 & 3rd person & FEM & feminine \\
ABL & ablative & GEN & genitive \\
ACC & accusative & ILL & illative \\
ALL & allative & INE & inessive \\
CNG & connegative & INSTR & instrumental \\
DEF & definite & LAT & lative
\end{tabular}




$\begin{array}{llll}\text { MASC } & \text { masculine } & \text { PTCP } & \text { participle } \\ \text { NEG } & \text { negative } & \text { REFL } & \text { reflexive } \\ \text { ORD } & \text { ordinal } & \text { SG } & \text { singular } \\ \text { PL } & \text { plural } & \text { TRA } & \text { transitive } \\ \text { PRP } & \text { prepositional } & \text { VN } & \text { verbal noun } \\ \text { PRS } & \text { present } & \text { VOC } & \text { vocative } \\ \text { PST } & \text { past } & & \end{array}$

\section{References}

\section{Data sources}

Doronin 1996 = Доронин, Александр: Баягань сулейть. Роман. Саранск: Мордовской книжной издательствась.

Erkay 1991 = Эркай, Никул: Алёшка. Повесть. Для сред. Шк. Возраст. Саранск: Мордовской книжной издательствась.

Kliuchagin 1997 = Ключагин, Пётр: Цёканька. Ёвтнемат. Средней ды старшей классо тонавтницятнень туртов. Саранск: Мордовской книжной издательствась.

MV I = Mordwinische Volksdichtung. 1938. Gesammelt von H. Paasonen. Herausgeben und übersetzt von Paavo Ravila. I. Band. Mémoires de la Société Finno-Ougrienne 77. Helsinki: Finno-Ugrian Society.

MV II = Mordwinische Volksdichtung. 1939. Gesammelt von H. Paasonen. Herausgeben und übersetzt von Paavo Ravila. II. Band. Mémoires de la Société Finno-Ougrienne 81. Helsinki: Finno-Ugrian Society.

Paltin \& al. 1997 = Палтин Ю. М., Петрушкин Н. И., Разгуляева Т. В., Рузавина В. М., Ерюшев Б. А.: Оиёр. Ёвтнемат. Средней ди старшей классо тонавтнициятнень туртов. Саранск: Мордовской книжной издательствась.

Siatko 2003: 1, 2, 3, 4, 7 and $10=$ Material from Erzya journal Siatko, the Volga server of the Research Unit for Volgaic Languages, University of Turku.

\section{Other references}

Aikio, Ante \& Jussi Ylikoski 2007: Suopmelaš gielaid l-kásusiid algovuođđu sáme- ja eará fuolkegielaid čuovggas. - Jussi Ylikoski \& Ante Aikio (eds), Sámit, sánit, sátmehánit. Riepmočála Pekka Sammallahtii miessemánu 21. beaivve 2007. Mémoires de la Société Finno-Ougrienne 253. Helsinki: Finno-Ugrian Society. 11-71.

Bartens, Raija 1996: Über die Deklination im Mordwinischen. Finnisch-Ugrische Forschungen 53. Helsinki: Finno-Ugrian Society. 1-113.

Bartens, Raija 1999: Mordvalaiskielten rakenne ja kehitys. Mémoires de la Société FinnoOugrienne 232. Helsinki: Finno-Ugrian Society.

Bereczki, Gábor 1988: Geschichte der wolgafinnischen Sprachen. - Dennis Sinor (ed.), The Uralic Languages. Description, history and foreign influences. Leiden: E. J. Brill. 314350.

Creissels, Denis 2011: The functive (alias essive): syncretisms and grammaticalization paths. Workshop on Role Complexes. (New) approaches to defining semantic roles. April 4-5, 2011, University of Zurich. <http://www.deniscreissels.fr/public/Creissels-functive.pdf $>$ 
Cygankin et al. 2000 = Цыганкин, Д. В., Агафонова, Н. А., Имайкина, М. Д., Мосин, М. В., Цыпкайкина, В. П., Абрамова, Е. А. (eds): Эрзянь кель. Морфология. Саранск: Мордовской книжной издательствась.

Erelt, Mati \& Metslang, Helle 2003: Case marking of the predicative in Estonian. - Linguistica Uralica 39. Tallinn: Teaduste Akadeemia Kirjastus. 166-173.

Grünthal, Riho 2003: Finnic adpositions and cases in change. Mémoires de la Société FinnoOugrienne 244. Helsinki: Finno-Ugrian Society.

ISK = Auli Hakulinen, Maria Vilkuna, Riitta Korhonen, Vesa Koivisto, Tarja Riitta Heinonen \& Irja Alho: Iso suomen kielioppi. 2004. Helsinki: Finnish Literature Society.

Hamari, Arja 2008: The negation of stative relation clauses in the Mordvin languages. Mémoires de la Société Finno-Ougrienne 254. Helsinki: Finno-Ugrian Society.

Haspelmath, Martin 2010. Comparative concepts and descriptive categories in crosslinguistic studies. - Language 86-3. 663-687.

Janhunen, Juha 1989: Samojedin predestinatiivisen deklinaation alkuperästä. - Journal de la Société Finno-Ougrienne 82: 298-301.

Kangasmaa-Minn, Eeva 1993: On the non-attributive adjective in the Finno-Ugric languages. - Ural-altaische Jahrbücher 12. Bloomington: Eurolingua. 74-81.

Koliadenkov 1954 = Коляденков, М. Н.: Грамматика мордовских (эрзянского и мокшанского) языков. Часть II. Синтаксис. Саранск: Мордовской книжной издательствась.

Koliadenkov 1959 = Коляденков, М. Н.: Структура простого предложения в мордовских языках. Предложение и его главные члены. Саранск: Мордовской книжной издательствась.

Kont, Karl 1955: Translatiivist läänemeresoome keeltes ja mordva ning lapi keeles. - Emakeele Seltsi Aastaraamat 1. Tallinn: Eesti NSV teaduste akadeemia, Emakeele Selts. 163-170.

Koptjevskaja-Tamm, Maria \& Dahl, Östen 2001: The Circum-Baltic languages: An areal typological approach. - Östen Dahl \& Maria Koptjevskaja-Tamm (eds), Circum-Baltic Languages. Volume 2. Grammar and Typology. Studies in Language Companion Series. Amsterdam/Philadelphia: John Benjamins. 615-750.

Laakso, Johanna 2005: Johdon ja taivutuksen diakronisista suhteista. - Johanna Vaattovaara, Toni Suutari, Hanna Lappalainen \& Riho Grünthal (eds), Muuttuva muoto. Kirjoituksia Tapani Lehtisen 60-vuotispäivän kunniaksi. Kieli 16. Helsinki: Helsingin yliopiston suomen kielen laitos. 93-109.

Lehtinen, Tapani 2007: Kielen vuosituhannet: suomen kielen kehitys kantauralista varhaissuomeen. Helsinki: Finnish Literature Society.

Nichols, Johanna 1981: Predicate Nominals. A Partial Surface Syntax of Russian. BerkeleyLos Angeles - London: University of California Press.

Pai, Kristina 2001: Essiivne ja translatiivne predikatiivadverbiaal. - Reet Kasik (ed.), Keele kannul. Pühendusteos Mati Erelti 60. sünnipäevaks 12. märtsil 2001. Tartu Ülikooli eesti keele õppetooli toimetised 17. Tartu: University of Tartu. 232-249.

Pajunen, Anneli 2000: Suomen ominaisuuspredikaatio ja tyyppi olla sairaana. - Anneli Pajunen (ed.), Näkökulmia kielitypologiaan. Suomi 186. Helsinki: Finnish Literature Society. 36-87.

Riese, Timothy 1993: Der Translativ in den uralischen Sprachen II. - Linguistica Uralica 29. 1-20. Tallinn. 
Saarinen, Sirkka 2001: Das finnisch-wolgaische Ableitungssuffix *kse. - Néprajz és nyelvtudomány XLI/2, Szeged: Jate BTK. 241-247.

Stassen, Leon 1997: Intransitive Predication. Oxford: Clarendon Press.

Stassen, Leon 2001: Nonverbal predication in the Circum-Baltic Languages. - Östen Dahl \& Maria Koptjevskaja-Tamm (eds), Circum-Baltic Languages. Volume 2. Grammar and Typology. Studies in Language Companion Series. Amsterdam/Philadelphia: John Benjamins. 569-590.

Timberlake, Alan 2004: A Reference Grammar of Russian. Cambridge: Cambridge University Press.

Turunen, Rigina 2009: A typology of non-verbal predication in Erzya. - Acta Linguistica Hungarica 56. Budapest: Akadémiai Kiadó. 251-313.

Turunen, Rigina 2010a: The relationship between person and number agreement in Erzya non-verbal predicate constructions. - Finnisch-Ugrische Forschungen 60. Helsinki: Finno-Ugrian Society. 71-116.

Turunen, Rigina 2010b: Nonverbal predication in Erzya. Studies on morphosyntactic variation and part-of-speech distinctions. Dissertation for PhD. Tallinn.

Turunen, Rigina 2011: Parts of speech in non-typical function: (a)symmetrical encoding of non-verbal predicates in Erzya. - Linguistic Discovery.

Zaicz, Gábor 1998: Mordva. - Daniel Abondolo (ed.), The Uralic Languages. London: Routledge. 184-218.

Rigina Turunen $<$ rigina.turunen@helsinki.fi $>$ 